\title{
Analysis of water quality in the Pelagatos ravine after the spill of the former mining company Pushaquilca through Grey Clustering
}

\author{
Alexi Delgado ${ }^{1}$, Hassan Zarria ${ }^{1}$, Johan Ramirez ${ }^{1}$, Gresli Camargo ${ }^{1}$, Angela Cornelio ${ }^{1}$, Ch. Carbajal ${ }^{2}$ \\ ${ }^{1}$ Mining Engineering Section, Pontificia Universidad Católica del Perú, Lima-Peru, kdelgadov@ pucp.edu.pe \\ ${ }^{2}$ Administration Program, Universidad de Ciencias y Humanidades, Lima-Peru, chcarbajal@uch.edu.pe
}

\begin{abstract}
The area that involves the Santa river watershed is characterized by its mining potential, this fact has generated the existence of environmental mining liabilities. Therefore, it is necessary to evaluate water quality in areas where there may be an impact caused by a former mine harming mains rivers in the surrounding areas. In this work, we apply the center-point triangular whitenization weight functions (CTWF) method, which is based on the grey systems theory that is an approach from artificial intelligence. In the case study, we analyzed monitoring points (after the accident) near the area affected by a tailings spill, these points correspond to the Pelagatos ravine that co-flows with the Santa river. The monitoring data were obtained from Water National Authority of Peru (ANA by its Spanish acronym). The CTWF method was applied using parameters of water quality such as $\mathrm{Ph}, \mathrm{OD}$, $\mathrm{SS}, \mathrm{Fe}$, and $\mathrm{Mn}$. Then, the results were ranked using the Prati scale. Consequently, the results showed that $80 \%$ of the monitoring points were classified as contaminated including points highly contaminated. Finally, the results of this study could be used by local authorities, supervision organisms, government or the company in charge of closing the liabilities to make the best decision on the affected area.
\end{abstract}

Key words : Grey Systems, Tailings Spills, Water Quality, Whitenization-weight Functions.

\section{INTRODUCTION}

In June 14th of 2019, the Pelagatos ravine located in the department of Ancash, Peru, were affected by the spill of tailings from the former Pushaquilca mine (LME Pushaquilca)[1], which generated that the National Water Authority of Peru (ANA by its spanish acronym) carried out an analysis of pollutants in the water near the accident area, according to the National Protocol for Monitoring the quality of Water Resources [2]. Therefore, in this work, we seek to determine the level of contamination of five points in the affected area using the grey clustering method[3], [4] with the
Prati Scale [5], [6] in order to classify the points and register the damage; as a water assessment is crucial for the correct development and welfare of the nearby communities and animals, as well as the ecosystem of the surrounding areas [7]. The grey clustering method is based on grey systems theory and is part of artificial intelligence, which was developed in 1985 by Deng [8], [9]. This method consists of developing a series of equations called whitening functions (CTWF), which will allow classifying what is observed with the name of grey classes to determine the level of contamination of the object analyzed [9]-[12].

The study area corresponds to the Pelagatos ravine [13], in which 5 monitoring points located downstream from where the mining effluent flowed [2] will have the following codes: Qpush 01, Qpush 02, Lpesc 03, Lpesc 02 and Lpesc 01.

The main objective of the work study is to classify the water quality level of the Pelagatos ravine after the tailings spill occurred in the area, using the CTWF method in order to have a registry of the water quality, as a foundation to analyze in future studies and see the impact in case a remediation has been applied or not in the mentioned area by the company in charge of closing the liabilities. By using the method, the Prati scale will classify the points as: excellent (drinking water), acceptable (water for agriculture), polluted (not usable) and highly polluted (harmful to life) in order to have a scale of the contamination if any.

In the following section, a literature review is given in order to obtain a better understood of the benefits of the methodology. Likewise, the presentation of the methodology of the present article is describedin details by its equations and steps to be performed in section 3 . Then the case study will be displayed in section 4, where the location of the affected area, the control points, and the parameters to be taken will be found.In section 5, the results of the application along with its discussionscan be seen. Lastly, the conclusions are shown in section 6 .

\section{LITERATURE REVIEW}

The evaluation of water quality plays an important role in environmental science[14], [15]. Due to several factors, a 
rational pattern must be chosen to objectively describe the quality of the environment.

The first study to be evaluated is in the Tambobamba district, Cotabambas province, in the Apurímac region [3]. Las Bambas mine is operating in this area, which influences the Challhuahuacho and Ferrobamba rivers. Through the monitoring of 6 points carried out by the ANA it was possible to know the degree of contamination of these rivers. Carrying out the grey clustering methodology and the water parameters by the peruvian DS $\mathrm{N}^{\circ}$ 004-2017-MINAM. This paper concluded that the water in the Ferrobamba river has high water quality, while the Challhuahuacho river has poor quality associated with spills in the area.

Another case reference of the use of the chosen methodology is the Fuyang River, which has great value for industrial and agriculture in Handan [16]. However, in recent years monitoring of water in this river has indicated contamination. Given this, the grey clustering evaluation of the water quality was established using aquatic plants that purify the water of the FuYang River. For this evaluation, the Grey Clustering method was used, analyzing 7 monitoring points where the plants were located, the method allowed to distinguish the level of water quality, which indicates that the river has a gradually good water purification cycle, but in some months it is different and may be due to the change in the temperature of the climate and the decomposition of the aquatic plant itself. On the study [17], the Fenchuan River is a level 1 tributary of the Yellow River that flows from the eastern slope of Jiu Long Spring Lao Mountain in Nanniwan. This river is an important resource for the industry and agriculture in the Baota area, and it was decided to carry out a quality evaluation of this river through the application of Grey Clustering, therefore samples were collected from the upstream, midstream, downstream and leaving boundary spot of Fengchuan River respectively in October 2008. The evaluation in this article is classified into five levels, is based on water quality standard in Environmental Quality Standards for Surface Water (GB3838-2002), that is, in five grey classes. The result indicated that the quality of the Fengchuan water in the Baota area was contaminated to different degrees and different solutions were proposed that can counteract the degree of contamination of the river.

Finally, in [18], the Grey Clustering Method has been used to evaluate the water quality of 20 sections of the Suzhou River in Jiangsu Province, China in order to do a comparison with the results obtained by the traditional method.

Consequently, once we have analyzed the variety of studies that have used the Grey Clustering methodology (which cannot be analyzed in its full width since it exceeds the possibilities of the present article), we conclude that the method is completely adjustable to the field of study with the objective of evaluating water quality.

\section{METHODOLOGY}

In this section, we explain the Grey Clustering method, which will be applied in the evaluation of the water quality of 5 monitoring points belonging to sectors of the Pelagatos ravine. For which we begin with information from works that present the same methodology considered in the literature review.

First, a set of $n$ monitoring points, a set of $m$ water quality parameters, a set of $s$ grey classes and a set of real monitoring data $x_{i j}(i=1,2, \ldots, m ; j=1,2, \ldots, n)$ will be defined. Then, the steps of the CTWF method are presented as follows [9], [14], [16]-[19].

Step 1:The non-dimensional standard values for each water quality parameter $(j)$ are established, according to the Prati scale [5]. Subsequently, monitoring data is obtained from all the non-dimensional study points of each water quality parameter, for each monitoring point to be evaluated $(i)$.

Step 2:The five grey classes from Prati scale are shown in Figure 1.

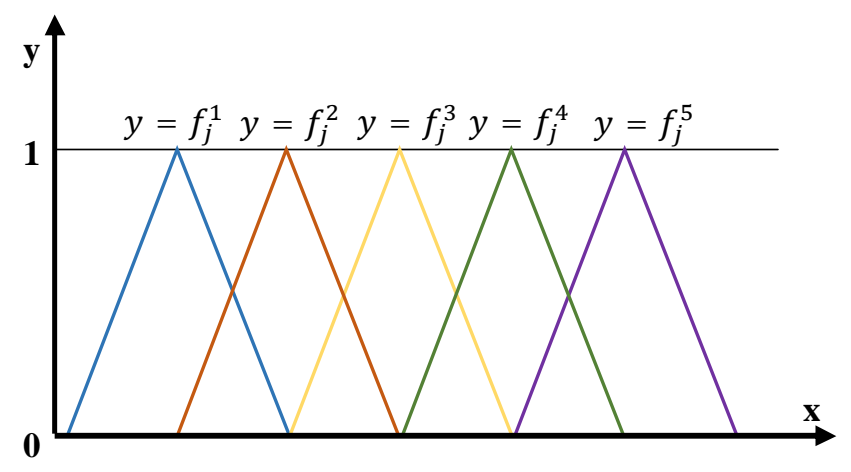

Where:

Figure 1: CTWF according to Prati scale

$$
\begin{aligned}
& y=f_{j}^{1}: \text { Uncontaminated. } \\
& y=f_{j}^{2}: \text { Acceptable. } \\
& y=f_{j}^{3}: \text { Moderately contaminated. } \\
& y=f_{j}^{4}: \text { Contaminated. } \\
& y=f_{j}^{5}: \text { Highly contaminated. }
\end{aligned}
$$

Then, the grey classes or criteria will be denoted by the letter $k$ where $(k=1,2,3,4,5)$ of the $j^{t h}$ parameter $(j=$ $1,2, \ldots, n)$ for a monitoring value $x_{i j}$; the CTWF will be calculated by (1) - (3)

$$
\begin{gathered}
f_{j}^{1}\left(x_{i j}\right)=\left\{\begin{array}{c}
1,\left[0, \lambda_{j}^{1}\right] \\
\frac{\lambda_{j}^{2}-x}{\lambda_{j}^{2}-\lambda_{j}^{1}}, x<\lambda_{j}^{1}, \lambda_{j}^{2}> \\
0, x\left[\lambda_{j}^{2},+\infty>\right.
\end{array}\right. \\
f_{j}^{k}\left(x_{i j}\right)=\left\{\begin{array}{c}
\frac{x-\lambda_{j}^{k-1}}{\lambda_{j}^{k}-\lambda_{j}^{k-1}}, x\left[\lambda_{j}^{k-1}, \lambda_{j}^{k}\right] \\
\frac{\lambda_{j}^{k+1}-x}{\lambda_{j}^{k+1}-\lambda_{j}^{k}}, x<\lambda_{j}^{k}, \lambda_{j}^{k+1}> \\
0, x\left[0, \lambda_{j}^{k-1}\right] U\left[, \lambda_{j}^{k+1}+\infty>\right.
\end{array}\right. \\
f_{j}^{5}\left(x_{i j}\right)=\left\{\begin{array}{c}
\frac{x-\lambda_{j}^{4}}{\lambda_{j}^{5}-\lambda_{j}^{4}}, x<\lambda_{j}^{4}, \lambda_{j}^{5}> \\
1, x\left[\lambda_{j}^{5},+\infty>\right. \\
0, x\left[0, \lambda_{j}^{4}\right]
\end{array}\right.
\end{gathered}
$$


Step 3:The clustering weight $\left(\eta_{j}\right)$ of each parameter is obtained, according to the values of the Prati scale, which is calculated by (4).

$$
\eta_{j}^{k}=\frac{1 / \lambda_{j}^{k}}{\sum_{j=1}^{m} 1 / \lambda_{j}^{k}}
$$

Step 4:The integral clustering coefficient $\sigma_{i}^{k}$ for each monitoring point $i, i=1,2, \ldots, m$, with respect to the grey class $k, k=1,2, \ldots, s$, is calculated by (5).

$$
\sigma_{j}^{k}=\sum_{j=1}^{n} f_{j}^{k}\left(x_{i j}\right) \cdot \eta_{j}
$$

Where $f_{j}^{k}\left(x_{i j}\right)$ is the value of grey clustering and $\eta_{j}$ is the weight of parameter $\mathrm{j}$.

Step 5:The maximum clustering coefficient value is analyzed; $\max \left\{\sigma_{i}^{k}\right\}=\sigma_{j}^{k}$, and it is decided which object $i$ belongs to the grey class $\mathrm{k}$.

\section{CASE STUDY}

On June 14th of 2019, there was a spill of an Environmental Mining Liabilities left by the former mine Pushaquilca that damaged the Pelagatos ravine and empties into the Santa River. For this reason, the National Water Authority from Peru (ANA by its Spanish acronym) performed a contaminant analysis in the water near the accident zone.

The affected area was delimited by 5 monitoring points to carry out water control from different parameters. For this, the Grey Clustering method will be carried out to evaluate the values of the results.

\subsection{Context Description}

The context of this area is regarding a spill of environmental liabilities of the former mine Pushaquilca located in the Pampas district, Pallasca, Ancash near the Pelagatos ravine where this environmental mining pollution could affect it considerably. The location is close to the coordinates -77.89977; -8.16469 (WGS84); for a better appreciation see Figure 2.

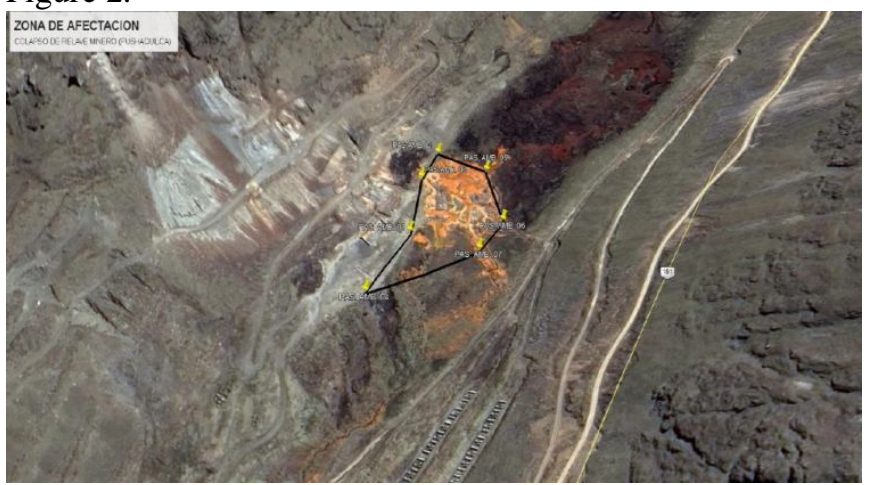

Figure 2: Location of the area where the mine tailings collapse occurred

As mentioned before, 5 control points were made in order to make a more-in-detail analysis, such control point are located in the ravine of Pelagatos which is displayed in Figure 3.

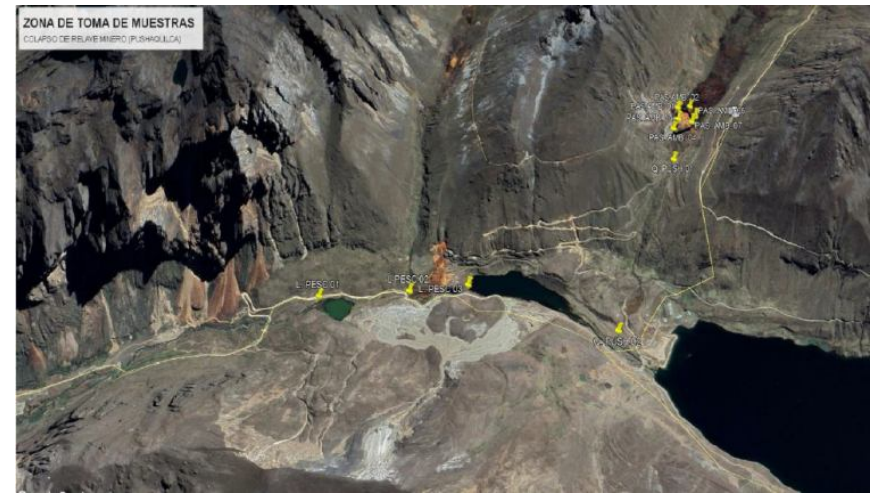

Figure 3:Satellite image of the monitoring point

In addition, the coordinates of such control points are displayed in Table 1.

Table 1: Monitoring points

\begin{tabular}{|c|c|c|c|c|}
\hline Monitori & \multirow{2}{*}{ Code } & \multirow{2}{*}{ Description } & \multicolumn{2}{|c|}{ Coordinates } \\
\cline { 4 - 5 } & & East & North \\
\hline 1 & $\begin{array}{c}\text { QPush } \\
1\end{array}$ & $\begin{array}{c}\text { Quebrada } \\
\text { Pushaquilca 1 }\end{array}$ & 190943 & $\begin{array}{c}909618 \\
1\end{array}$ \\
\hline 2 & $\begin{array}{c}\text { QPush } \\
2\end{array}$ & $\begin{array}{c}\text { Quebrada } \\
\text { Pushaquilca 2 }\end{array}$ & 190583 & $\begin{array}{c}909538 \\
4\end{array}$ \\
\hline 3 & LPesc3 & $\begin{array}{c}\text { Laguna } \\
\text { Pescuezona 3 }\end{array}$ & 189922 & $\begin{array}{c}909562 \\
0\end{array}$ \\
\hline 4 & LPesc2 & $\begin{array}{c}\text { Laguna } \\
\text { Pescuezona 2 }\end{array}$ & 189651 & $\begin{array}{c}909559 \\
7\end{array}$ \\
\hline 5 & LPesc1 & $\begin{array}{c}\text { Laguna } \\
\text { Pescuezona 1 }\end{array}$ & 189234 & $\begin{array}{c}909558 \\
8\end{array}$ \\
\hline
\end{tabular}

\subsection{Calculations using the Grey Clustering Method}

The calculations for the case studyare presented below, in order to do the analysis through the Grey Clustering Method, the steps presented in section 3 will be followed.

Step 1:First, the parameters of the dimensioned standard values, according to the Prati scale is presented in Table 2.

Table 2: Standard dimensioned data

\begin{tabular}{|c|c|c|c|c|c|}
\hline & $\boldsymbol{\lambda}_{\mathbf{1}}$ & $\boldsymbol{\lambda}_{\mathbf{2}}$ & $\boldsymbol{\lambda}_{\mathbf{3}}$ & $\boldsymbol{\lambda}_{\mathbf{4}}$ & $\boldsymbol{\lambda}_{\mathbf{5}}$ \\
\hline Basic $\mathrm{pH}$ & 1.350 & 1.164 & 1.024 & 0.829 & 0.633 \\
\hline $\mathrm{OD}$ & 0.672 & 0.797 & 0.925 & 1.177 & 1.429 \\
\hline $\mathrm{SS}$ & 0.082 & 0.247 & 0.577 & 1.557 & 2.537 \\
\hline $\mathrm{Fe}$ & 0.044 & 0.177 & 0.531 & 1.593 & 2.655 \\
\hline $\mathrm{Mn}$ & 0.052 & 0.231 & 0.702 & 1.572 & 2.442 \\
\hline
\end{tabular}

The monitoring data obtained by the National Water Authority (ANA) for each parameter of each control point, the results of which were dimensioned, are presented in Table 3.

Table 3: Monitoring data

\begin{tabular}{|c|c|c|c|c|c|}
\hline & QPush1 & QPush2 & LPesc3 & LPesc2 & LPesc1 \\
\hline pH & 0.63 & 0.63 & 1.56 & 1.45 & 1.55 \\
\hline OD & 0.04 & 0.05 & 0.05 & 0.05 & 0.05 \\
\hline SS & 0.12 & 0.09 & 0.008 & 0.03 & 0.02 \\
\hline Fe & 9.91 & 5.33 & 0.20 & 1.54 & 0.64 \\
\hline Mn & 4.1048 & 3.667 & 0.203 & 0.493 & 0.284 \\
\hline
\end{tabular}


Step 2:The values of the Table of standardized data (Table 1) added are used to perform the following equations in order to obtain the grey clustering of the 5 points. As an example, the equations of the fourth parameter $(\mathrm{Fe})$ are shown below:

$$
\begin{gathered}
f_{4}^{1}\left(x_{i j}\right)=\left\{\begin{array}{c}
1, \quad x \in[0,0.044] \\
\frac{0.177-x}{0.177-0.044}, x \in\langle 0.044,0.177\rangle \\
0, x \in[0.177,+\infty]
\end{array}\right. \\
f_{4}^{2}\left(x_{i j}\right)=\left\{\begin{array}{l}
\frac{x-0.044}{0.177-0.044}, x \in\langle 0.044,0.177\rangle \\
\frac{0.531-x}{0.531-0.177}, x \in\langle 0.177,0.531\rangle \\
0, x \in[0,0.044] \cup[0.531,+\infty]
\end{array}\right. \\
f_{4}^{3}\left(x_{i j}\right)=\left\{\begin{array}{l}
\frac{x-0.177}{0.531-0.177}, x \in\langle 0.177,0.531\rangle \\
\frac{1.593-x}{1.593-0.531}, x \in\langle 0.531,1.593\rangle \\
0, x \in[0,0.177] \cup[1.593,+\infty]
\end{array}\right. \\
f_{4}^{4}\left(x_{i j}\right)=\left\{\begin{array}{c}
\frac{x-0.531}{1.593-0.531}, x \in\langle 0.531,1.593\rangle \\
\frac{2.655-x}{2.655-1.593}, x \in\langle 1.593,2.655\rangle \\
0, x \in[0,0.531] \cup[2.655,+\infty]
\end{array}\right. \\
f_{4}^{5}\left(x_{i j}\right)=\left\{\begin{array}{c}
\frac{x-1.593}{2.655-1.593}, x \in\langle 1.593,2.655\rangle \\
1, x \in[2.655,+\infty\rangle \\
0, x \in[0,1.593]
\end{array}\right.
\end{gathered}
$$

Step 3:The weight of the criteria according to grey clustering for each parameter, in each value of the Prati scale, according to (4) is calculated. The results are shown in Table 4.

Table 4: Clustering weight of the parameters

\begin{tabular}{|c|c|c|c|c|c|}
\hline & $\boldsymbol{\lambda}_{\mathbf{1}}$ & $\boldsymbol{\lambda}_{\mathbf{2}}$ & $\boldsymbol{\lambda}_{\mathbf{3}}$ & $\boldsymbol{\lambda}_{\mathbf{4}}$ & $\boldsymbol{\lambda}_{\mathbf{5}}$ \\
\hline Basic pH & 0.01 & 0.05 & 0.14 & 0.30 & 0.46 \\
\hline $\mathrm{OD}$ & 0.03 & 0.08 & 0.15 & 0.21 & 0.20 \\
\hline $\mathrm{SS}$ & 0.22 & 0.25 & 0.24 & 0.16 & 0.11 \\
\hline $\mathrm{Fe}$ & 0.40 & 0.35 & 0.27 & 0.16 & 0.11 \\
\hline $\mathrm{Mn}$ & 0.34 & 0.27 & 0.20 & 0.16 & 0.12 \\
\hline
\end{tabular}

Step 4:The clustering coefficients were obtained by means of (5), such results are displayed in Table 5.

Table 5: Values of CTWF and $\sigma_{i}^{k}$ for each parameter

\begin{tabular}{|c|c|c|c|c|c|c|}
\hline QPush1 & $\boldsymbol{C}_{\mathbf{1}}$ & $\boldsymbol{C}_{\mathbf{2}}$ & $\boldsymbol{C}_{\mathbf{3}}$ & $\boldsymbol{C}_{\mathbf{4}}$ & $\boldsymbol{C}_{\mathbf{5}}$ & $\boldsymbol{\sigma}_{\boldsymbol{i}}^{\boldsymbol{k}}$ \\
\hline$f_{j}^{1}(x)$ & 0.00 & 1.00 & 0.75 & 0.00 & 0.00 & 0.189 \\
\hline$f_{j}^{2}(x)$ & 0.00 & 0.00 & 0.25 & 0.00 & 0.00 & 0.054 \\
\hline$f_{j}^{3}(x)$ & 0.00 & 0.00 & 0.00 & 0.00 & 0.00 & 0.000 \\
\hline$f_{j}^{4}(x)$ & 0.00 & 0.00 & 0.00 & 0.00 & 0.00 & 0.000 \\
\hline$f_{j}^{5}(x)$ & 1.00 & 0.00 & 0.00 & 1.00 & 1.00 & 0.757 \\
\hline QPush2 & $\boldsymbol{C}_{\mathbf{1}}$ & $\boldsymbol{C}_{\mathbf{2}}$ & $\boldsymbol{C}_{\mathbf{3}}$ & $\boldsymbol{C}_{\mathbf{4}}$ & $\boldsymbol{C}_{\mathbf{5}}$ & $\boldsymbol{\sigma}_{\boldsymbol{i}}^{\boldsymbol{k}}$ \\
\hline$f_{j}^{1}(x)$ & 0.00 & 1.00 & 0.95 & 0.00 & 0.00 & 0.232 \\
\hline$f_{j}^{2}(x)$ & 0.00 & 0.00 & 0.05 & 0.00 & 0.00 & 0.011 \\
\hline
\end{tabular}

\begin{tabular}{|c|c|c|c|c|c|c|c|c|}
\hline Points & $\begin{array}{l}\lambda \\
1\end{array}$ & $\begin{array}{l}\lambda \\
2\end{array}$ & $\begin{array}{l}\lambda \\
3\end{array}$ & $\begin{array}{l}\lambda \\
4\end{array}$ & $\begin{array}{l}\lambda \\
5\end{array}$ & $\begin{array}{l}\text { Max. } \\
\text { value }\end{array}$ & $\lambda$ & $\begin{array}{l}\text { Descrip } \\
\text { tion }\end{array}$ \\
\hline QPush1 & $\begin{array}{l}0 . \\
1 \\
9\end{array}$ & $\begin{array}{l}0 . \\
0 \\
5\end{array}$ & 0 & 0 & $\begin{array}{l}0 . \\
7 \\
6\end{array}$ & 0.76 & $\lambda 5$ & $\begin{array}{c}\text { Highly } \\
\text { contami } \\
\text { nated }\end{array}$ \\
\hline QPush2 & $\begin{array}{l}0 . \\
2 \\
3 \\
\end{array}$ & $\begin{array}{l}0 . \\
0 \\
1 \\
\end{array}$ & 0 & 0 & $\begin{array}{l}0 . \\
7 \\
6\end{array}$ & 0.76 & $\lambda 5$ & $\begin{array}{c}\text { Highly } \\
\text { contami } \\
\text { nated }\end{array}$ \\
\hline LPesc3 & $\begin{array}{l}0 . \\
3 \\
1 \\
\end{array}$ & $\begin{array}{l}0 . \\
6 \\
7 \\
\end{array}$ & $\begin{array}{l}0 . \\
0 \\
2 \\
\end{array}$ & 0 & 0 & 0.67 & $\lambda 2$ & $\begin{array}{l}\text { Aceptab } \\
\text { le }\end{array}$ \\
\hline LPesc2 & $\begin{array}{l}0 . \\
2 \\
6\end{array}$ & $\begin{array}{l}0 . \\
1 \\
5\end{array}$ & $\begin{array}{l}0 . \\
2 \\
1\end{array}$ & $\begin{array}{l}0 . \\
3 \\
8\end{array}$ & 0 & 0.38 & $\lambda 4$ & $\begin{array}{c}\text { Contam } \\
\text { nated }\end{array}$ \\
\hline LPesc1 & $\begin{array}{l}0 . \\
2 \\
6\end{array}$ & $\begin{array}{l}0 . \\
3\end{array}$ & $\begin{array}{l}0 . \\
4\end{array}$ & $\begin{array}{l}0 . \\
0 \\
4\end{array}$ & 0 & 0.4 & $\lambda 3$ & $\begin{array}{c}\text { Slightly } \\
\text { contami } \\
\text { nated }\end{array}$ \\
\hline
\end{tabular}

\begin{tabular}{|c|c|c|c|c|c|c|}
\hline$f_{j}^{3}(x)$ & 0.00 & 0.00 & 0.00 & 0.00 & 0.00 & 0.000 \\
\hline$f_{j}^{4}(x)$ & 0.00 & 0.00 & 0.00 & 0.00 & 0.00 & 0.000 \\
\hline$f_{j}^{5}(x)$ & 1.00 & 0.00 & 0.00 & 1.00 & 1.00 & 0.757 \\
\hline $\mathbf{L P e s c 3}$ & $\boldsymbol{C}_{\mathbf{1}}$ & $\boldsymbol{C}_{\mathbf{2}}$ & $\boldsymbol{C}_{\mathbf{3}}$ & $\boldsymbol{C}_{\mathbf{4}}$ & $\boldsymbol{C}_{\mathbf{5}}$ & $\boldsymbol{\sigma}_{\boldsymbol{i}}^{\boldsymbol{k}}$ \\
\hline$f_{j}^{1}(x)$ & 1.00 & 1.00 & 1.00 & 0.00 & 0.15 & 0.308 \\
\hline$f_{j}^{2}(x)$ & 0.00 & 0.00 & 0.00 & 0.95 & 0.85 & 0.670 \\
\hline$f_{j}^{3}(x)$ & 0.00 & 0.00 & 0.00 & 0.05 & 0.00 & 0.022 \\
\hline$f_{j}^{4}(x)$ & 0.00 & 0.00 & 0.00 & 0.00 & 0.00 & 0.000 \\
\hline$f_{j}^{5}(x)$ & 0.00 & 0.00 & 0.00 & 0.00 & 0.00 & 0.000 \\
\hline $\mathbf{L P e s c 2}$ & $\boldsymbol{C}_{\mathbf{1}}$ & $\boldsymbol{C}_{\mathbf{2}}$ & $\boldsymbol{C}_{\mathbf{3}}$ & $\boldsymbol{C}_{\mathbf{4}}$ & $\boldsymbol{C}_{\mathbf{5}}$ & $\boldsymbol{\sigma}_{\boldsymbol{i}}^{\boldsymbol{k}}$ \\
\hline$f_{j}^{1}(x)$ & 1.00 & 1.00 & 1.00 & 0.00 & 0.00 & 0.256 \\
\hline$f_{j}^{2}(x)$ & 0.00 & 0.00 & 0.00 & 0.00 & 0.44 & 0.151 \\
\hline$f_{j}^{3}(x)$ & 0.00 & 0.00 & 0.00 & 0.05 & 0.56 & 0.209 \\
\hline$f_{j}^{4}(x)$ & 0.00 & 0.00 & 0.00 & 0.95 & 0.00 & 0.384 \\
\hline$f_{j}^{5}(x)$ & 0.00 & 0.00 & 0.00 & 0.00 & 0.00 & 0.000 \\
\hline $\mathbf{L P e s c 1}$ & $\boldsymbol{C}_{\mathbf{1}}$ & $\boldsymbol{C}_{\mathbf{2}}$ & $\boldsymbol{C}_{\mathbf{3}}$ & $\boldsymbol{C}_{\mathbf{4}}$ & $\boldsymbol{C}_{\mathbf{5}}$ & $\boldsymbol{\sigma}_{\boldsymbol{i}}^{\boldsymbol{k}}$ \\
\hline$f_{j}^{1}(x)$ & 1.00 & 1.00 & 1.00 & 0.00 & 0.00 & 0.256 \\
\hline$f_{j}^{2}(x)$ & 0.00 & 0.00 & 0.00 & 0.00 & 0.89 & 0.302 \\
\hline$f_{j}^{3}(x)$ & 0.00 & 0.00 & 0.00 & 0.90 & 0.11 & 0.400 \\
\hline$f_{j}^{4}(x)$ & 0.00 & 0.00 & 0.00 & 0.10 & 0.00 & 0.041 \\
\hline$f_{j}^{5}(x)$ & 0.00 & 0.00 & 0.00 & 0.00 & 0.00 & 0.000 \\
\hline
\end{tabular}

Step 5:Finally, the condition "if $\max _{1 \leq \mathrm{k} \leq \mathrm{s}}\left\{\sigma_{\mathrm{i}}^{\mathrm{k} *}\right\}$ " is applied, then the objective $i$ belongs to grey class $k$. For each monitoring point; the results are shown in the following table.

\section{RESULTS AND DISCUSSION}

The discussion of the water quality evaluation, according to the specific objectives set for this study, is as follows: Firstly, from table VI we can conclude that $20 \%$ of the monitoring points have an "Acceptable" quality; $20 \%$ of the monitoring points have a "Slightly Contaminated" quality; $20 \%$ of the monitoring points have a "Contaminated" quality; and $40 \%$ of the monitoring points have a "Highly Contaminated" quality, according to the Prati scale. The 
monitoring points can be ordered in the following increasing order of contamination (by considering the higher value $\sigma_{i}^{k}$ ) :

LPesc3 $<$ LPesc1< LPesc2< QPush1= QPush2

LPesc3 presents the lowest degree of contamination, being classified in the $\lambda 2$ "Acceptable" category. In contrast, points QPush1 andQPush2 are the most contaminated and have the same affinity with category $\lambda 5$ "Highly contaminated".

Secondly, the heterogeneity in the results may be due to the limitation of the water to reach all the monitoring points at the same time and in the same quantity. In addition, diffusion factors that limit the permanence of certain pollutants in certain areas of the affected hydrographic system should not be discarded.

Thirdly, more evaluations are required for a correct design of remediation methods. The present study can only confirm or discard the degree of affection that water quality has had in a specific monitoring point.

Finally, the results are compatible with the ANA report[2], which indicates environmental damage to the water quality of the study area. It was observed that for the points Qpush1 and Qpush2 (which are the closest to the tailings spill), metallic contents respect to iron and manganese are the most critical and exceed the permissible limit according to Prati scale [5].

\section{CONCLUSIONS}

The surface waters of the Pelagatos ravine, which meets the Santa River, has a low quality level of water. Likewise, it is important to note that the area affected by the former mining company has nearby communities (Pampas's community) that use surface water for their activities. In this sense, Activos Mineros S.A.C., the company in charge of closing the mining liabilities, must execute the necessary and prompt measures to avoid negative effects on the health of the inhabitants, as well as another possible spill. In this sense, the results obtained in this study could help the organisms in charge of the supervision of surface waters and the local authorities to make the best decisions regarding the treatment and management to be applied to the waters that have suffered the impact of the tailings spill.

On the other hand, regarding the Grey Clustering method, it has been proven that it evaluates and classifies the monitoring points according to the water quality parameters reported by the ANA in an optimal manner. In addition to consider the difference in the influence of the water quality indicators established by the ANA, it also assigns the weights to each parameter depending on the degree of contamination of the different variables applied, and according to legislation or chosen scale.

In future studies, the Grey Clustering method could be used to assess to do a comparison of the impact before and after having carried out remediation treatments to improve the quality of water in the study area.

\section{REFERENCES}

1. Ancash: derrame de minera en aguas del río Santa se advertían hace 11 meses, Wayka, 21-Jun-2019.
2. E. Taboada, Toma de muestras de agua superficial ante la presunta contaminación causada, por el colapso de un relave minero, 2019.

3. A. Delgado, A. Espinoza, P. Quispe, P. Valverde, and C. Carbajal, Water quality in areas surrounding mining: Las Bambas, Peru, Int. J. Innov. Technol. Explor. Eng., vol. 8, no. 12, 2019.

4. A. Delgado, J. Culqui, G. Tasayco, A. Millán, E. Tirado, and C. Carbajal, Quality assessment of surface water associated with a copper mine in peruusinggrey systems, Int. J. Adv. Trends Comput. Sci. Eng., vol. 9, no. 4, pp. 6660-6668, 2020.

5. L. Prati, R. Pavanello, and F. Pesarin, Assessment of surface water quality by a single index of pollution, Water Res., vol. 5, no. 9, pp. 741-751, 1971.

6. A. Delgado, A. Aguirre, E. Palomino, and G. Salazar, Applying triangular whitenization weight functions to assess water quality of main affluents of Rimac river, in Proceedings of the 2017 Electronic Congress, E-CON UNI 2017, 2017, vol. 2018-January, pp. 1-4.

7. A. Delgado, B. Ortiz, R. Hurtado, R. Monge, A. Perez, and C. Carbajal, Applying grey systems to assess social impact on the extraction phase of the Palma mining project in Peru, Int. J. Adv. Trends Comput. Sci. Eng., vol. 9, no. 4, pp. 4295-4301, 2020.

8. J. Deng, Generation Functions of Grey Systems. Fuzzy Mathematics, 5th ed. .

9. S. Liu and Y. Lin, Grey Systems: Theory and Applications. Berlín: Springer, 2010.

10. P. An, L. Hu, T. $\mathrm{Li}$, and C. Li, Assessing the eutrophication of shengzhong reservoir based on grey clustering method, Chinese J. Popul. Resour. Environ., vol. 7, no. 2, pp. 83-87, 2009.

11. L. Hu, C. Zhang, C. Hu, and G. Jiang, Use of grey system for assessment of drinking water quality: A case S study of Jiaozuo city, China, in 2009 IEEE International Conference on Grey Systems and Intelligent Services, GSIS 2009, 2009, pp. 803-808.

12. W. C. Ip, B. Q. Hu, H. Wong, and J. Xia, Applications of grey relational method to river environment quality evaluation in China, J. Hydrol., vol. 379, no. 3-4, pp. 284-290, Dec. 2009.

13. OEFA ordena a Activos Mineros S.A.C. medidas administrativas inmediatas para evitar la afectación a la quebrada Pelagatos - OEFA.[Online]. Available: https://www.oefa.gob.pe/oefa-ordena-a-activos-mineross-a-c-medidas-administrativas-inmediatas-para-evitar-laafectacion-a-la-quebrada-pelagatos/ocac07/. [Accessed: 26-Aug-2020].

14. A. Delgado, M. Acuña, N. Justano, E. Llanos, and I. Puma, Water Quality Assessment in a Watershed in Cusco, Peru using the Grey Clustering Method, Int. J. Eng. Adv. Technol., vol. 9, no. 2, pp. 5093-5098, 2019.

15. J. Chen, S. Zhao, and Y. Weng, Research on river water quality assessment of eastern route of south-to-north water transfers based on grey cluster evaluation model, in 2009 IEEE International Conference on Grey Systems and Intelligent Services, GSIS 2009, 2009, pp. 882-887. 
Alexi Delgado et al., International Journal of Emerging Trends in Engineering Research, 8(10), October 2020, 7659 - 7664

16. S. Gu and F. Du, Research on the Purification Effect of Aquatic Plants Based on Grey Clustering Method, in IOP Conference Series: Materials Science and Engineering, 2018, vol. 301, no. 1.

17. L. Wang, K. Lai, and W. Zhou, Application of grey clustering method for water quality evaluation in Fenchuan river Yan'an Baota area, in ISWREP 2011 Proceedings of 2011 International Symposium on Water Resource and Environmental Protection, 2011, vol. 2, pp. 838-841.

18. C. Zhu and Q. Liu, Evaluation of water quality using grey clustering, in Proceedings - 2009 2nd International Workshop on Knowledge Discovery and Data Mining, WKKD 2009, 2009, pp. 803-805.

19. Y. Zhang, J. Ni, J. Liu, and L. Jian, Grey evaluation empirical study based on center-point triangular whitenization weight function of Jiangsu Province industrial technology innovation strategy alliance, Grey Syst. Theory Appl., vol. 4, no. 1, pp. 124-136, Jan. 2014. 